\title{
Sources of atmospheric pollution in the rust belt, Ohio, USA
}

\author{
Masoomeh Kousehlar ${ }^{1}$,Elisabeth Widom ${ }^{1, *}$, and David Kuentz ${ }^{1}$ \\ ${ }^{1}$ Department of Geology \& Environmental Earth Science, Miami University, Oxford, OH, USA
}

\begin{abstract}
Industrial regions in the rust belt are sites of significant legacy atmospheric pollution, and despite recent regulations, continue to be sites of ongoing atmospheric emissions of toxic metals. Source attribution in such areas is complicated by the presence of multiple potential point sources, including steel production plants and coal fired power plants. This study focuses on a region in Ohio, USA, in the vicinity of a steel manufacturing plant and coke production facility. Scanning electron microscopy of atmospheric particulate matter, combined with major and trace element and $\mathrm{Pb}$ and $\mathrm{Os}$ isotopic analysis of dust, lichen and tree bark, have been employed to identify the primary contributors to the atmospheric metal load. Our results suggest that steel production, coal burning, and traffic emissions are all significant sources of metals to the local environment.
\end{abstract}

\section{Introduction}

A major steel plant in Ohio, surrounded by urban residential areas, produces significant atmospheric emissions. According to EPA's toxic release inventory, the steel plant releases almost $22680 \mathrm{~kg}$ of nitrate, $\mathrm{Mn}, \mathrm{Ba}, \mathrm{Cu}$, and $\mathrm{Ni}$ compounds into the atmosphere annually [1]. Lead, $\mathrm{Cu}, \mathrm{Cr}$ and $\mathrm{Zn}$ in street sediments from a park adjacent to the steel plant show elevated concentrations compared to the local background [2]. In addition to air pollution, wastewater from the steel plant has made a nearby creek one of the most contaminated waterways in the state based on high PCB concentration [3]. An additional source of contamination in this area is a coke plant, which is a raw material handling and processing plant that provides coke for the steel and power industry. The Coke plant releases $18700 \mathrm{~kg}$ of $\mathrm{Pb}, \mathrm{Hg}, \mathrm{HCl}, \mathrm{H}_{2} \mathrm{SO}_{4}$ to the atmosphere annually [1]. However, no study to date has evaluated air pollution in this area, despite the presence of the steel plant as a significant metal emitting source.

In this study, we used lichen and tree bark to evaluate the relative contributions of steel and other potential sources, including traffic and the local coke production facility, to the atmospheric heavy metal load in the area. Lichen and tree bark have been used effectively to monitor airborne contamination (e.g. [4,5]). Lichens are considered particularly good indicators of air quality because they lack root systems, thus the substratum on which they grow does not contribute to their metal accumulation [6]. Both lichens and tree bark occur widely in areas of varying human influence, and provide long-term records of metal pollutant accumulation [7].

Isotopic techniques can be used for identifying sources of contamination in different environmental samples such as soil, dust, water, and biological material (e.g. tree bark and lichen), and the spread and variation in isotopic ratios make isotopes a powerful tool when it comes to detecting the sources of anthropogenic pollution. Lead isotopes have served as a tracer for source discrimination of metals in environmental studies for a long time, and are often useful for identifying the impact of fossil fuel combustion (e.g. [8,9]). However, to reduce the uncertainties in atmospheric pollutant source identification, a multi-tracer approach that combines elemental and multiple isotopic systems is often necessary. Prior studies have demonstrated that osmium isotopic ratios and concentrations can be particularly useful in tracing emissions related to steel production [10,11]. Therefore, in this study, we have applied both $\mathrm{Pb}$ and $\mathrm{Os}$ isotopes, as well as elemental concentrations of metals, to investigate the predominant sources of atmospheric pollution in the rust belt of Ohio. These techniques can be applied globally in similar industrial regions.

\footnotetext{
* Corresponding author: widome@ miamioh.edu
} 


\section{Materials and Methods}

Major and trace element abundances, and $\mathrm{Pb}$ and $\mathrm{Os}$ isotopic compositions, were measured by Inductively Coupled Plasma Optical Emission Spectroscopy (ICP-OES) and Thermal Ionization Mass Spectrometry (TIMS), respectively. Particulate matter (PM) from each potential source was acquired by a Sigma-2 passive sampler, which accumulates dry deposition (dust) during the collection period. Scanning Electron Microscopy with Energy Dispersive X-ray spectroscopy (SEM/EDX) was used to determine particle morphology, size distribution, and chemical compositions.

\section{Results and Discussion}

Morphological observations by SEM show that dust samples are composed of geogenic, anthropogenic, and biological particles that range in equivalent diameter from $<10 \mathrm{~nm}$ to $200 \mu \mathrm{m}$. Dust samples collected close to the steel plant contain abundant iron (Fe-oxide), Mn-, and $\mathrm{Zn}$-rich particles, consistent with the abundance of these metals in steel production processes.

Lichen samples collected near the steel plant, coke production facility, and a background lichen sample exhibit highly variable metal concentrations. The lichen sample collected as a background proxy, in a nearby area with minimal industrial influence, contains the lowest abundances of all elements. Iron, $\mathrm{Pb}$, Mo, and $\mathrm{V}$ show minor to moderate enrichments compared to the background, while $\mathrm{Cr}, \mathrm{Mn}, \mathrm{Ni}$, and $\mathrm{Zn}$ display a wide range of enrichment factors (EFs) and show moderately severe to severe enrichment in some areas. Cobalt, $\mathrm{Cr}, \mathrm{Mn}, \mathrm{Zn}, \mathrm{V}, \mathrm{Ni}$, and $\mathrm{Fe}$ concentrations increase with proximity to the steel plant. The highest Mo concentration is observed close to the steel plant and coke production facility, and the highest $\mathrm{Pb}$ concentrations are found in the center of the urban area. Dust collected near the coke production facility exhibits the highest $\mathrm{Cr}, \mathrm{V}, \mathrm{Mn}$, and Mo concentrations, and the highest $\mathrm{Zn}$ and $\mathrm{Cu}$ concentrations are measured in traffic dust. Arsenic, $\mathrm{Cd}, \mathrm{Co}, \mathrm{Ni}$, and $\mathrm{Pb}$ concentrations in dust samples were below detection limit, due most likely to the small sample mass.

Lead $(\mathrm{Pb})$ isotopic ratios of lichen show a wide range for ${ }^{206} \mathrm{~Pb} /{ }^{204} \mathrm{~Pb},{ }^{207} \mathrm{~Pb} /{ }^{204} \mathrm{~Pb}$, and ${ }^{208} \mathrm{~Pb} /{ }^{204} \mathrm{~Pb}$. In ${ }^{208} \mathrm{~Pb} /{ }^{204} \mathrm{~Pb}-$ ${ }^{206} \mathrm{~Pb} /{ }^{204} \mathrm{~Pb}$ space, the samples exhibit a positive correlation and plot in a three-end member mixing envelope defined by the steel plant, background, and a relatively unradiogenic source, most likely traffic-related (Fig. 1). The same mixing relationships are also observed in ${ }^{208} \mathrm{~Pb} /{ }^{206} \mathrm{~Pb}-{ }^{207} \mathrm{~Pb} /{ }^{206} \mathrm{~Pb}$ and ${ }^{206} \mathrm{~Pb} /{ }^{204} \mathrm{~Pb}$ versus $1 / \mathrm{Pb}$ and $1 / \mathrm{Cr}$ plots. The sample collected close to the coke plant and a few other samples show slightly elevated ${ }^{208} \mathrm{~Pb} /{ }^{204} \mathrm{~Pb}$, interpreted as a contribution from coal.

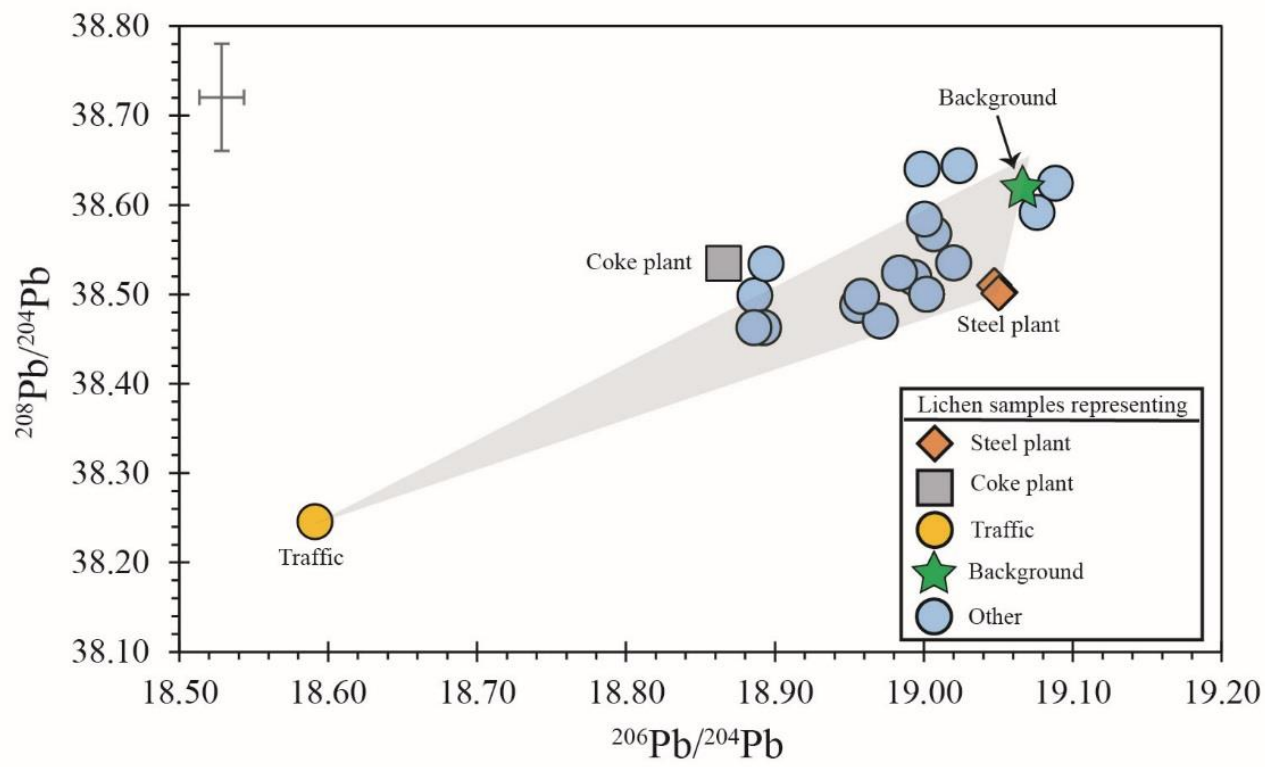

Fig. 1. ${ }^{208} \mathrm{~Pb} /{ }^{204} \mathrm{~Pb}$ versus ${ }^{206} \mathrm{~Pb} /{ }^{204} \mathrm{~Pb}$ showing the isotopic composition of lichen samples from the study area. Triangular space highlighted by gray shows the three end-member mixing between the background, steel plant and traffic related emissions. Error bar are represented in the top left corner of the plot. 
Four bark samples have been analyzed for Re-Os isotopes, including two in close proximity to the steel plant, one near the coke plant, and one background sample. The highest Os and Re concentrations were measured in bark samples collected close to the steel plant. The least radiogenic ${ }^{187} \mathrm{Os} /{ }^{188} \mathrm{Os}$ ratios were measured in the bark sample collected closest to the steel plant, and the most radiogenic ratio recorded in the background sample. On a ${ }^{187} \mathrm{Re}^{/ 188} \mathrm{Os}$ vs. ${ }^{187} \mathrm{Os} /{ }^{188} \mathrm{Os}$ diagram, the steel and coke samples plot on a linear trend, with the background bark samples plotting distinctly off the trend. These preliminary data suggest that the Re-Os budgets are controlled primarily by contaminant sources that effectively mask any background contribution. The Os isotopic composition of steel should reflect the Os isotopic compositions of the materials used for its production (i.e. iron ore, coal in the form of coke, limestone, and chromite) [12]. The relatively unradiogenic signature of tree bark near the steel plant is consistent with a significant influence from chromite, typically derived from low Re/Os, ultramafic sources. Additional tree bark, lichen and dust analyses are in progress to further constrain the relative contribution of coal, traffic and steel plant emissions to the Re and platinum group element (PGE) budget of the atmosphere in this industrial rust belt region.

\section{Conclusions}

Lichen and tree bark are effective biomonitors of pollutant emissions from the steel industry and associated coke production facilities. Lead isotopic data suggest that the steel plant, traffic and background all contribute to the atmospheric metal load. Preliminary Os isotopic data indicate that the Re-Os budgets are dominated by anthropogenic sources including coal and the steel industry.

We thank Dr. Richard Edelmann and Mr. Matt Duley of Miami University's Center for Advanced Microscopy and Imaging (CAMI) for their assistance with the microscopy. This study has been supported by the Janet \& Elliot Baines Professorship awarded to E. Widom.

\section{References}

1. U.S. EPA. Toxic Release Inventory Public Data Release (2016)

2. Dietrich, M., Huling, J., Krekeler, M.P.S. (2018). Metal pollution investigation of Goldman Park, Middletown Ohio: evidence for steel and coal pollution in a high child use setting. Sci. Total Environ. 618, 1350-1362

3. Burton GA Jr., Greenberg MS., Rowland CA., Irvine CA., Lavoie DR., Brooker JA., Moore L., Raymer DFM., McWilliam RA. In situ exposures using caged organisms: A multi-compartment approach to detect aquatic toxicity and bioaccumulation. Environ Pollut, 134,133-144 (2005)

4. Catinon M., Ayrault S., Spadini L., Boudouma O., Tissut M., Ravanel P. Tree bark suber-included particles: a long-term accumulation site for elements of atmospheric origin. Atmos. Environ., 45, 1102-1109 (2011)

5. Agnan Y., Sejalon-Delmas N., Probst A. Investigation of spatial and temporal metal atmospheric deposition in France through lichen and moss bioaccumulation over one century. Science of Total Environment, 487, 1-12 (2015)

6. Brown A.L. Increasing the utility of urban environmental quality information. Landscape and Urban Planning, 65, 85-93 (2003)

7. Asta J., Erhardt W., Ferretti M., Fornasier F., Kirschbaum U., Nimis P.L., Purvis O., Pirintsos S., Scheidegger C., Van Haluwyn C., Wirth V. Mapping lichen diversity as an indicator of environmental quality. In: Nimis, P.L., Scheidegger, C., Wolseley, P. (Eds.), Monitoring with Lichens - Monitoring Lichens. Kluwer Academic Publishers, The Netherlands, 273-279 (2002)

8. Ault WA., Senechal RG., Erlebach WE. Isotopic composition as a natural tracer of lead in the environment. Environmental Science and Technology, 4, 305-311 (1970)

9. Haack UK., Gutsche FH., Plessow K., Heinrichs H. On the isotopic composition of $\mathrm{Pb}$ in cloud waters in central Germany. a source discrimination study. Water Air Soil Pollution, 139, 261-88 (2002)

10. Rodushkin, I., Engstrom, E., Sorlin, D., Baxter, D., Hornfeldt, B., Nyholm, E., et al. Uptake and accumulation of anthropogenic Os in free-living bank voles (Myodes glareolus). Water Air Soil Pollut. 218, 603-610 (2011)

11. Rodushkin, I., Engström, E., Sörlin, D., Pontér, C., Baxter, D.C. Osmium in environmental samples from Northeast Sweden. Part II. Identification sources. Sci. Total Environ. 386, 159-168 (2007)

12. Chatterji R.N. Os isotopic compositions of mantle peridotites and steels: Implications for Pt-Re-Os evolution of the Earth's upper mantle and continental crust. Ph.D. Dissertation, University of Texas, Austin (2016) 